10.Омаров А.Е.о. Механізми формування та реалізації державної політики екологічної безпеки України : автореф. дис. ... докт. наук з держ. упр.: 25.00.05. Харків, 2019. 41 с.

11. Лазор О.Я. Адміністративно-правові засади державного управління у сфері реалізації екологічної політики в Україні : автореф. дис. ... докт. наук з держ. упр.: 25.00.02. Київ, 2004. $36 \mathrm{c}$.

12.Плахотній С.А. Удосконалення системи управління екологічною безпекою атмосферного повітря та гідрогеологічного середовища навколо вугільних шахт : автореф. дис. ... канд. техн. наук: 21.06.01. Київ, 2017. 20 с.

13.Павличенко А.В. Екологічна небезпека експлуатації та ліквідації вугільних шахт: методологія оцінки, напрями і засоби зниження : автореф. дис. ... докт. техн. наук: 21.06.01. Дніпро, 2017. 36 с.

14.Екологічна безпека вугільних родовищ України / за ред. Г.І. Рудька, О.І. Бондаря. Київ ; Чернівці : Букрек, 2016. 608 с.

15.Пльохова А.Ю. Стадії забезпечення екологічної безпеки при видобуванні вугілля: правові аспекти. Геологія горючих копалин: досягнення та перспективи : матеріали Міжнародної науково-практичної конференції, м. Київ, 2-5 вересня 2019 р. Київ: Інститут геологічних наук НАН України, 2019. 168 с. С. 158-163.

16.Гірничий закон України від 6 жовтня 1999 р. № 1127-XIV. URL: https://zakon.rada. gov.ua/laws/show/1127-14.

ЧОПКО Х. I.,

кандидат юридичних наук, асистент кафедри соціального права (Львівський національний університет імені Івана Франка)

\title{
ОКРЕМІ ПРАВОВІ АСПЕКТИ ЕКОЛОГІЧНОГО НОРМУВАННЯ В УКРАЇНІ ТА ШЛЯХИ ЙОГО ВДОСКОНАЛЕННЯ
}

Стаття присвячена аналізу правового регулювання екологічного нормування в Україні. 3 метою збереження навколишнього природного середовища, якість якого повинна бути задовільною та сприятливою для людини, визначено межі допустимого негативного впливу на довкілля. Орієнтовний перелік екологічних нормативів передбачений у Законі України «Про охорону навколишнього природного середовища», серед яких: нормативи гранично допустимих викидів (ГДВ) в атмосферне повітря та гранично допустимих скидів (ГДС) у воду, грунти забруднюючих хімічних речовин, а також гранично допустимих рівнів (ГДР) фізичних чинників, зокрема шуму, вібрації, іонізуючого випромінювання (радіаціі), електромагнітних чинників, а також шкідливих біологічних чинників, тобто будь-яких чинників біотичного походження (віруси, бактерії, грибки, токсини тощо), що здатні спричиняти масові захворювання людей, тварин, рослин, а також погіршити стан довкілля. На всій території України діє уніфікована система екологічних нормативів. Три показники покладено в основу екологічного нормування, а саме медичний (максимальний рівень загрози

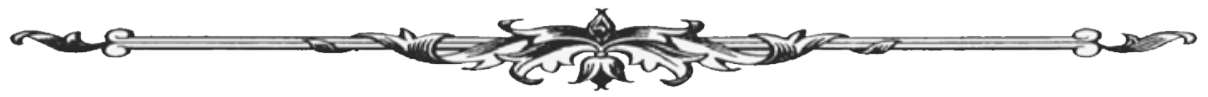


здоров’ю людини, іiі генетичній програмі), технологічний (можливість економіки забезпечити виконання визначених меж впливу на людину і довкілля) і науково-технічний (здатність науково-технічних засобів контролювати дотримання меж впливу за всіма його параметрами). Існуюча в Україні система екологічних нормативів недостатньо розвинена та не охоплює всіх аспектів безпеки довкілля. Більшість екологічних нормативів застарілі, що зумовлює необхідність у запроваджені додаткових, більш практичних критеріїв якості навколишнього природного середовища, зокрема специфіка того чи іншого регіону, аналіз впливу складних сполук, що існують на території відповідного населеного пункту, рівень здоров’я населення й інших живих організмів за регіонами.

Ключові слова:якість довкілля, екологічненормування, екологічні нормативи, система екологічних нормативів, показники екологічного нормування.

The article is devoted to the analysis of legal regulation of environmental regulation in Ukraine. In order to preserve the environment, the quality of which must be satisfactory and favorable to humans, the limits of the permissible negative impact on the environment have been determined. An indicative list of environmental standards is provided in the Law of Ukraine "On Environmental Protection", including: maximum permissible emissions into the air and maximum permissible discharges into water, soils of polluting chemicals, and soils of polluting chemicals permissible levels of physical factors, including noise, vibration, ionizing radiation (radiation), electromagnetic factors, as well as harmful biological factors, any factors of biological origin (Viruses, bacteria, fungi, toxins, etc.) that can cause massive disease in humans, animals, plants, and degrade the environment. There is a unified system of environmental standards throughout Ukraine. Three indicators form the basis of environmental rationing, namely medical (the maximum level of threat to human health, its genetic program), technological (the ability of the economy to meet certain limits of impact on humans and the environment) and scientific and technical (the ability to control scientific and technical means adherence to the limits of influence in all its parameters). The existing system of environmental standards in Ukraine is underdeveloped and does not cover all aspects of environmental safety. Most environmental standards are outdated, which necessitates the introduction of additional, more practical criteria for the quality of the environment, including the specificity of a region, analysis of the effects of complex compounds existing on the territory of the locality, the level of health of the population and other living organisms by region.

Key words: environmental quality, environmental regulation, environmental rationing, system of environmental standards, indicators of environmental rationing.

Вступ. Національна екологічна політика України спрямована на досягнення низки стратегічних цілей, серед яких підвищення рівня суспільної екологічної свідомості, поліпшення екологічної ситуації та досягнення безпечного для життя і здоров'я людини стану довкілля.

Найповніше втілюється механізм забезпечення права громадян на безпечне для життя і здоров'я довкілля через встановлення сумісності з довкіллям усіх напрямів діяльності. Інакше кажучи, в історії людства настав такий момент, коли вирішення будь-яких соціальних проблем тісно пов'язане із завданням збереження біосфери та їі компонентів. Критеріями добробуту тепер є не лише кількість природних благ, що безпосередньо потрапляють у сферу споживання, а й якість природного середовища, що оточує людину.

Деякою мірою негативний вплив на довкілля дозволений, оскільки людство не може існувати і розвиватись, не впливаючи на довкілля. Щоб зберегти довкілля, якість якого

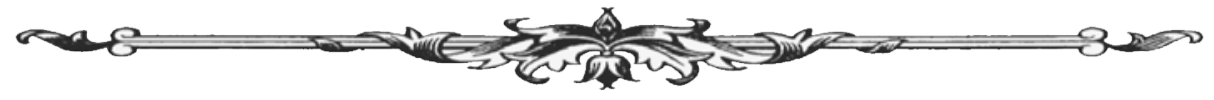


повинна бути задовільною та сприятливою для людини, необхідно визначити межі негативного впливу на довкілля шляхом його нормування. Тому одним із важливих правових інститутів екологічного права та здійснюваних державою заходів із запобігання негативному впливу на довкілля є нормування такого впливу, екологічне нормування.

Проблематику екологічного нормування розглядали у своїх роботах В. Андрейцев, Т. Бакунін, Г. Бистров, Г. Випханов, В. Бредіхіна, М. Краснова, Н. Малишева, Ю. Шемшученко й інші.

Постановка завдання. Метою статті $є$ дослідження поняття «екологічне нормування», аналіз існуючої системи екологічних нормативів та показників, що покладені в основу екологічного нормування в Україні.

Результати дослідження. Екологічне нормування, або нормування негативних впливів на стан довкілля, тлумачиться як діяльність спеціально уповноважених державних органів щодо розробки та затвердження меж допустимого впливу на довкілля, хімічного забруднення, фізичних, біологічних та інших шкідливих чинників, що походять від стаціонарних та пересувних джерел, а також обсягів використання природних ресурсів та дозволених природно перетворюючих заходів з урахуванням сучасного рівня розвитку науки і техніки, а також економічних передумов [1, с. 196]. Орієнтовний перелік екологічних нормативів передбачений у ст. 33 Закону України «Про охорону навколишнього природного середовища», серед яких: нормативи гранично допустимих викидів (далі - ГДВ) в атмосферне повітря та гранично допустимих скидів (далі - ГДС) у воду, грунти забруднюючих хімічних речовин, а також гранично допустимих рівнів (далі - ГДР) фізичних чинників, зокрема шуму, вібрації, іонізуючого випромінювання (радіації), електромагнітних чинників, а також шкідливих біологічних факторів, тобто будь-яких чинників біотичного походження (віруси, бактерії, грибки, токсини тощо), що здатні спричиняти масові захворювання людей, тварин, рослин, а також погіршити стан довкілля.

Відповідно до змін, внесених до Закону України «Про охорону навколишнього природного середовища» від 6 квітня 2000 р., до екологічних нормативів не належать нормативи екологічної безпеки [2]. Однак саме ці нормативи є єдиними критеріями якості навколишнього природного середовища. Мова йде про нормативи гранично допустимих концентрацій (далі - ГДК) забруднюючих речовин у воді, повітрі, грунті, у продуктах харчування та тваринних кормах, а також про рівні шкідливих фізичних та біологічних впливів на навколишнє природне середовище. Нормативи цієї групи називають «гігієнічними нормативами». Гранично допустимі концентрації диференціюються за видом забруднюючих речовин і типом природного ресурсу, у якому ці речовини поширюються.

Водночас, як зазначає Ю. Шемшученко, законодавством забезпечується правовий зв'язок між гранично допустимими концентраціями і гранично допустимими викидами та скидами у довкілля забруднюючих речовин, рівнями допустимого впливу на нього фізичних і біологічних чинників, адже останні встановлюються для кожного джерела хімічного, акустичного, електромагнітного, іонізуючого й інших фізичних і біологічних чинників на рівні, за якого хімічний, фізичний і біологічний вплив усіх джерел у цьому районі з урахуванням перспектив його розвитку в період терміну дії встановленого нормативу не призведе до перевищення нормативів ГДК [3, с. 218].

Екологічні нормативи єдині на всій території України. Однак у разі необхідності для курортних, лікувально-оздоровчих, рекреаційних і деяких інших регіонів можуть встановлюватися більш суворі нормативи гранично допустимих концентрацій забруднюючих речовин та інших шкідливих впливів на довкілля. В основу екологічного нормування покладені три показники: медичний (максимальний рівень загрози здоров'ю людини, іiі генетичній програмі), технологічний (можливість економіки забезпечити виконання визначених меж впливу на людину і довкілля) і науково-технічний (здатність науково-технічних засобів контролювати дотримання меж впливу за всіма його параметрами) [4, с. 64].

Відповідно до п. 2 ст. 33 Закону України «Про охорону навколишнього природного середовища», законодавством серед екологічних нормативів можуть бути встановлені нормативи використання природних ресурсів [2]. Вказані нормативи визначають можливі обсяги вилучення природних ресурсів із метою забезпечення їх збереження та запобі-

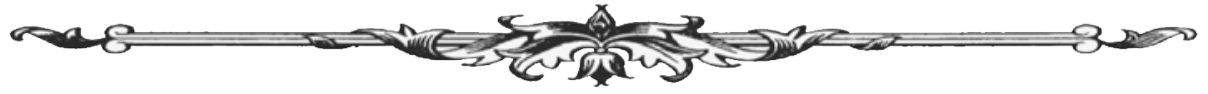


гання деградації природних ресурсів. Нормативи можливого вилучення природних ресурсів та порядок встановлення таких нормативів визначаються природоресурсними актами. Зокрема, відповідно до Закону України «Про тваринний світ» (ст. 16), полювання на парнокопитних тварин, куниць лісову та кам'яну, норку американську, тхора лісового, бобра, нутрію вільну, ондатру, бабака, білку здійснюється відповідно до лімітів, що затверджуються на мисливський сезон спеціально уповноваженим центральним органом виконавчої влади в галузі охорони навколишнього природного середовища за поданням спеціально уповноваженого центрального органу виконавчої влади в галузі мисливського господарства та полювання на підставі пропозицій користувачів мисливських угідь, погоджених із місцевими органами спеціально уповноваженого центрального органу виконавчої влади в галузі охорони навколишнього природного середовища в Автономній Республіці Крим, областях, містах Києві, Севастополі та місцевими органами спеціально уповноваженого центрального органу виконавчої влади в галузі мисливського господарства та полювання [5].

Згідно зі ст. 72 Лісового кодексу України, у лісах без завдання їм шкоди може здійснюватися заготівля другорядних лісових матеріалів: живиці, пнів, лубу та кори, деревної зелені, деревних соків. Ліміти використання лісових ресурсів під час заготівлі другорядних лісових матеріалів встановлюються відповідними органами влади за поданням органу виконавчої влади з питань лісового господарства Автономної Республіки Крим, територіальних органів центрального органу виконавчої влади з питань лісового господарства, погодженим з органом виконавчої влади $з$ питань охорони навколишнього природного середовища Автономної Республіки Крим, територіальними органами центрального органу виконавчої влади 3 питань охорони навколишнього природного середовища [6].

Отже, екологічні нормативи покликані визначати межі впливу людської діяльності на довкілля для того, щоб якість останнього була сприятливою для життя і здоров'я людини. Вони визначають прийнятний стан довкілля та допустимі рівні негативного впливу на нього. Фактично такі нормативи є правовим способом визначення максимально можливого негативного впливу на довкілля, за якого воно не втрачає можливостей самовідновлення і не шкодить життю та здоров’ю людей.

Водночас система існуючих в Україні екологічних нормативів ще недостатньо розвинена та не охоплює всі аспекти безпеки довкілля. Насамперед неможливо встановити нормативи для всіх шкідливих речовин та їхніх сполук. Затверджені екологічні нормативи неспроможні повноцінно формувати безпечне довкілля і через те, що більшість чинних в Україні природоохоронних правил і нормативів установлені на базі досягнень санітарно-гігієнічної науки 60-х рр. ХХ ст., в основу яких покладено витратно-екстенсивний підхід до розвитку природокористування. Наприклад, Міністерством охорони здоров'я затверджені Державні санітарні правила охорони атмосферного повітря населених місць (від забруднення хімічними та біологічними речовинами), які містять гігієнічні нормативи допустимого вмісту забруднюючих речовин в атмосферному повітрі населених місць [7]. Дані правила введено в дію 1 січня 1998 р. замість «Санитарных правил по охране атмосферного воздуха населенных мест» № 4946-89 (Москва, 1989 р.), вони є загальнодержавним нормативним документом і додержання їх - обов'язкове для міністерств і відомств, підприємств, установ, організацій усіх форм власності, посадових осіб і громадян.

Різниця між встановленими Міністерством охорони здоров'я гігієнічними нормативами і фактичним станом атмосферного повітря показує ступінь загрози атмосферного повітря життю і здоров'ю людини. Однак доцільно враховувати таку обставину, що під час визначення безпечної якості атмосферного повітря за критерій беруться нормативи, встановлені в 1989 р., що ставить під сумнів об’єктивність визначення ступеня його безпеки.

Застарілість багатьох екологічних нормативів зумовлює необхідність у введенні додаткових, більш практичних критеріїв якості навколишнього природного середовища, зокрема екологічного нормування шляхом відповідного квотування та ліцензування виробництв 3 орієнтацією їх на найбільш перспективні технології, що мінімально впливатимуть на якість навколишнього природного середовища. В. Андрейцев такий норматив екологічної безпеки називає рівнем екологічно безпечної діяльності [8, с. 11]. Варто зазначити, що такий вид екологічного нормування широко застосовується в багатьох закордонних країнах.

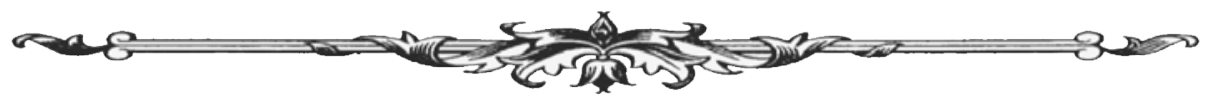


Зокрема, у Російській Федерації серед перелічених у Законі «Про охорону довкілля» видів екологічних нормативів передбачений такий вид нормативу, як технологічний, суть якого полягає у встановленні нормативу використання найсучасніших технологій з урахуванням економічних і соціальних чинників [9, с. 50-51].

У країнах Євпропейського Союзу з метою запровадження технологічних нормативів державами проводяться жорсткі економічні програми щодо підприємств, які не використовують найновіші технології. Зокрема, підприємство, яке використовує устаткування, що не відповідає новим технологіям, змушене обирати - модернізувати своє обладнання чи припиняти діяльність. Наприклад, у Польщі місцеві газопроводи сконструйовані виключно для задоволення потреб домашнього господарства, для приготування їжі, а не для опалення. Отже, екологічне нормування відбувається шляхом розподілу газу в тих районах, де особливо високий вміст твердих частинок та/або діоксину сірки в повітрі [10].

3 метою вдосконалення і спрощення процедури встановлення факту порушення суб'єктивного права громадян на екологічну безпеку, на думку В. Андрейцева, доцільно в Законі України «Про охорону навколишнього природного середовища» закріпити такий уніфікований норматив екологічної безпеки, як рівень природної безпеки [9, с. 11]. Зважаючи на те, що не до кінця вивчено наслідки впливу на життя і здоров'я людини шкідливих речовин у межах затверджених норм, вказаний норматив не можна так однозначно запровадити.

Уважаємо за необхідне ввести як критерій встановлення якості довкілля рівень здоров'я населення й інших живих організмів. Саме здоров'я людей окремого регіону є індикатором безпеки довкілля, тобто показником його небезпеки [11]. Схожі міркування має i В. Бредіхіна, яка пропонує під час визначеня безпеки довкілля враховувати таку обставину, як середня тривалість життя населення, середній вік осіб, які проживають у регіоні, рівні тимчасової непрацездатності, загальної захворюваності, смертності й інші [12, с. 181]. Водночас наявність показників здоров'я населення є недостатньою для з'ясування безпеки довкілля. Адже навряд чи можна вважати безпечним навколишнє природне середовище, показники якого відповідають встановленим екологічним нормативам, але проживання в якому пов'язане з високим ступенем екологічного й техногенного ризику. У різних регіонах країни чи на конкретній місцевості у зв'язку з різноманітними кліматичними умовами, наявністю або відсутністю на визначеній території екологічно небезпечних об'єктів можлива і різна міра небезпеки останнього для людини. Екологічні нормативи повинні бути встановлені для кожного конкретного регіону чи місця проживання людини. Тобто потрібна диференціація екологічних нормативів за регіонами з коригуванням їх стосовно відповідних чинників.

Варто зазначити, що вже є спроби застосування диференційованого способу екологічного нормування. Зокрема, Закон України «Про правовий режим територій, які зазнали впливу радіоактивного забруднення внаслідок Чорнобильської катастрофи» регулює питання поділу території на відповідні зони з визначенням режиму їх використання й охорони [12, с. 182]. Відповідно до ст. 1 цього Закону, території, які зазнали впливу радіоактивного забруднення внаслідок Чорнобильської катастрофи, за ступенем радіоактивного забруднення поділені на чотири зони: зона відчуження; зона безумовного (обов'язкового) відселення; зона гарантованого добровільного відселення; зона посиленого радіоекологічного контролю.

Так, на території зон гарантованого добровільного відселення, посиленого радіоекологічного контролю заборонено вносити пестициди, гербіциди, отрутохімікати без спеціального дозволу відповідних органів Кабінету Міністрів України. Така інтегральна оцінка безпеки довкілля використовується в Російській Федерації і називається нормативами допустимого антропогенного навантаження на довкілля [13]. Вказані нормативи встановлюються для суб'єктів господарської та іншої діяльності з метою оцінки і регулювання впливу всіх стаціонарних, пересувних та інших джерел впливу на довкілля, розміщених у межах певної території чи акваторії. Нормативи допустимого антропогенного навантаження на довкілля встановлюються відповідно до величини допустимого сукупного впливу всіх джерел на довкілля чи окремі його компоненти в межах конкретної території чи акваторії, за дотримання яких забезпечується стійке функціонування природних систем і збереження біологічного розмаїття.

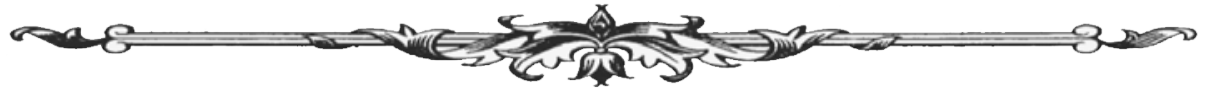


Так, навіть за дотримання підприємством гранично допустимих викидів в атмосферне повітря йому може бути встановлена межа викидів, нижча гранично допустимої, якщо стан навколишнього природного середовища в межах цієї території критичний [14].

Незважаючи на прогресивність механізму нормування, російські фахівці в галузі екологічного права звертають увагу і на його недоліки [15, с. 292]. Інститут екологічного нормування і стан його розвитку потребують переосмислення й оцінки, оскільки спроби введення нових видів нормативів у законодавстві $є$ недієвими, бо не були враховані нормативи допустимого техногенного навантаження, передбачені попереднім законом.

Висновки. Отже, щоб зберегти навколишнє природне середовище, якість якого повинна бути задовільною та сприятливою для людини, необхідно визначити межі негативного впливу на довкілля шляхом його нормування. Тому одним із важливих правових інститутів екологічного права та здійснюваних державою заходів із запобігання негативному впливу на довкілля є нормування такого впливу. Однак в існуючих екологічних нормативах не врахована специфіка того чи іншого регіону, не проаналізований вплив складних сполук, що існують на території відповідного населеного пункту. Як критерій встановлення якості довкілля вважаємо за необхідне запровадити і рівень здоров'я населення й інших живих організмів. Оскільки саме здоров'я людей на окремій території можна вважати об'єктивним індикатором безпеки довкілля, показником його небезпеки.

\section{Список використаних джерел:}

1. Малишева Н. Основні функції управління в галузі охорони навколишнього природного середовища / за заг. ред. Ю. Шемчушенка. Київ : Юрид. думка, 2008. С. 195-199.

2. Про охорону навколишнього природного середовища : Закон України від 25 червня 1991 р. / Верховна Рада України. Відомості Верховної Ради України. 1991. № 41. Ст. 540.

3. Екологічне право України. Академічний курс : підручник / за заг. ред. Ю. Шемшученка. 2-е вид. Київ : Юрид. думка, 2008. 720 с.

4. Право довкілля (екологічне право) : навчальний посібник для студентів закладів вищої освіти / П. Пилипенко та ін. ; за ред. П. Пилипенка. Київ : Ін Юре, 2010. 400 с.

5. Про тваринний світ : Закон України від 13 грудня 2001 р. № 2894-III / Верховна Рада України . Офіиійний вісник України. 2002. № 14. Ст. 97.

6. Лісовий кодекс України в редакції від 8 лютого 2006 р. / Верховна Рада України. Відомості Верховної Ради України. 2006. № 21. Ст. 170.

7. Про Державні санітарні правила охорони атмосферного повітря населених місць : наказ Міністерства охорони здоров’я від 9 липня 1997 р. № 201. URL : http://www.gorses. kh.ua/index.php/docs/snip/114-sniprechov.

8. Андрейцев В. Право громадян на екологічну безпеку: проблеми конституційно-правового забезпечення. Право Украӥни. 2001. № 4. С. 8-11.

9. Андрейцев В. Право екологічної безпеки в системі екологічного права України. Екологічне право: Особлива частина / за ред. В. Андрейцева. Київ : Істина, 2001. 171 с.

10. Экологическое право : учебник / Т. Бакунин и др. ; отв. ред. : Г. Быстров, Н. Жаворонкова, И. Краснова. Москва : Велби ; Проспект, 2007. 656 с.

11. Иноземцев В. Инновации с принуждением. Кремль.org : политическая экспертная сеть. URL: http://www.kreml.org/media/218843148.

12. Бредіхіна В. Щодо юридичних критеріїв безпеки навколишнього природного середовища. Республіканський міжвідомчий науковий збірник. Харків : Нац. юрид. академія України, 2008. Вип. 95. С. 180-184.

13.Про правовий режим територій, які зазнали впливу радіоактивного забруднення внаслідок Чорнобильської катастрофи : Закон України від 27 лютого 1991 р. / Верховна Рада УРСР. Відомості Верховної Ради УРСР. 1991. № 16. Ст. 198.

14. Про охорону довкілля : Федеральний закон РФ від 10 січня 2002 р. № 7-ФЗ. 33 РФ. 2002. № 2. СТ. 133 .

15. Краснова М. Концепция экологического нормирования в российском и зарубежном праве. Международный сборник научных трудов аграрных и юридических высших учебных заведений России, Украинь, Белоруссии, Казахстана, других стран СНГ и государств $E C$ : в 2-х т. Москва : ФГОУ ВПО РГАУ МСХА им. К.А. Тимирязева, 2009. Т. 2. С. 291-299.

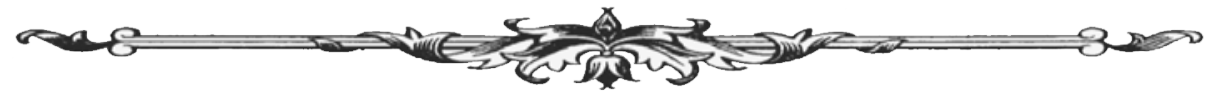

